\title{
ANALISIS NILAI-NILAI BUDAYA HUMA BETANG DALAM PEMBINAAN PERSATUAN KESATUAN BANGSA SISWA SMA DI KALIMANTAN TENGAH
}

\author{
Era Maresty, Zamroni \\ Program Studi Pendidikan Ilmu Pengetahuan Sosial, Pascasarjana, Universitas Negeri Yogyakarta \\ nera42@gmail.com, zamronihardjowirono@yahoo.com
}

\begin{abstract}
Abstrak
Penelitian ini bertujuan untuk mengungkapkan: (1) nilai-nilai budaya huma betang di Kalimantan Tengah, dan (2) pemanfaatan budaya huma betang dalam pembinaan rasa persatuan dan kesatuan bangsa pada siswa SMA di Kalimantan Tengah. Penelitian ini merupakan penelitian etnografi. Subjek penelitian yaitu masyarakat yang tinggal di huma betang desa Bontoi dan siswa SMAN 1 Kahayan Hilir. Data diperoleh dengan observasi partisipan, wawancara dan studi dokumentasi. Hasil penelitian menunjukkan bahwa: (1) budaya huma betang mengandung nilai religius, kebersamaan, kejujuran, toleransi, saling menghormati, kerja keras, musyawarah, gotong royong, mencintai alam, dan displin; (2) pemanfaatan nilai-nilai huma betang di SMA Kalimantan Tengah dalam membina rasa persatuan dan kesatuan bangsa dilakukan melalui berbagai kegiatan sekolah, baik kegiatan intrakurikuler maupun ekstrakurikuler. Pembinaan rasa persatuan dan kesatuan bangsa dengan memanfaatkan budaya huma betang dilakukan dalam kegiatan ekstrakurikuler, yang meliputi pramuka, pusat informasi dan konseling remaja, kerohanian, kesenian, olahraga, dan aksi pelajar peduli lingkungan.
\end{abstract}

Kata kunci: budaya huma betang, pembinaan rasa persatuan dan kesatuan bangsa

\section{AN ANALYSIS OF HUMA BETANG VALUES IN THE DEVELOPMENT OF UNITY OF THE STUDENTS OF SMA IN CENTRAL KALIMANTAN}

Era Maresty, Zamroni

Program Studi Pendidikan Ilmu Pengetahuan Sosial, Pascasarjana, Universitas Negeri Yogyakarta nera42@gmail.com, zamronihardjowirono@yahoo.com

\begin{abstract}
This research is aimed to reveal: (1) huma betang values in Central Kalimantan, and (2) the use of huma betang value in developing the sense of unity of the students of SMA in Central Kalimantan. This research was ethnographic research. The research subject was the community living in huma betang Buntoi and the students of SMA in Central Kalimantan. The data were collected through participant observation, interview and documentation study. The results of the research show that: (1) huma betang cultures contain the values of religiousity, togetherness, honesty, tolerance, mutual respect, perseverance, deliberation, cooperation, love of nature, and discipline; (2) the use of huma betang values at Central Kalimantan SMA in developing the sense of nation unity is conducted in school activities, both intracurricular and extracurricular activities. Developing the sense of nation unity using huma betang philosophy is conducted in extracurricular activities including scouting, youth counseling and information centre, religion, art, sport, and students care of environment.
\end{abstract}

Keywords: huma betang culture, developing sense of nation unity 


\section{Pendahuluan}

Secara geografis Indonesia merupakan negara kepulauan yang terdiri dari lebih dari 13 ribu pulau. Indonesia merupakan negara kesatuan yang terdiri dari berbagai keanekaragaman penduduknya yang tersebar di seluruh wilayah Republik Indonesia. Setiap pulau dihuni oleh komunitas masyarakat yang memiliki karakteristik sosial, budaya dan bahkan nilai dan keyakinan serta agama yang berbeda. "Bhineka Tunggal Ika" semboyan negara Indonesia yang mempunyai arti walaupun berbeda-beda tetapi tetap satu jua, mencerminkan keanekaragaman yang ada di Indonesia bukanlah suatu alasan untuk menjadi jurang pemisah melainkan menjadi sumber kekayaan bagi bangsa Indonesia.

Fakta bahwa Indonesia adalah negara yang majemuk yang di dalamnya tumbuh keberagaman etnik, budaya, agama, dan ras, adalah kenyataan yang harus diterima oleh kita sebagai suatu perbedaan yang sifatnya alamiah. Keanekaragaman bangsa Indonesia menjadi kekayaan khusus yang menarik, baik bagi bangsa Indonesia sendiri maupun bagi bangsa-bangsa lain di dunia sehingga dapat menarik devisa melalui kunjungan wisata atau kunjungan lainnya. Kemajemukan masyarakat Indonesia merupakan kekayaan dan kekuatan yang sekaligus juga menjadi tantangan bagi bangsa Indonesia. Tantangan itu terasa ketika bangsa Indonesia membutuhkan persatuan dan kesatuan bangsa dalam menghadapi dinamika kehidupan. Hal ini dikarenakan dalam mengatur masyarakat yang heterogen lebih sulit daripada mengatur masyarakat yang homogen. Masyarakat yang heterogen memiliki cita-cita, harapan dan keinginan yang lebih bervariasi dibandingkan dengan dalam masyarakat yang homogen.

Di tengah situasi masyarakat Indonesia yang multikultural tidak jarang dapat menimbulkan konflik. Di Kalimantan Tengah pernah terjadi konflik kekerasan terhadap etnik di Sampit, Kabupaten Kotawaringin Timur pada bulan Februari 2001 hingga menyebarluas sampai di beberapa kabupaten di Kalimantan Tengah. Dalam peristiwa itu ribuan nyawa warga Madura dan warga lokal dari Suku Dayak menjadi korban, dari anakanak sampai dengan orang dewasa, serta ratusan rumah warga Madura hangus terbakar. Peristiwa itu menimbulkan trauma yang sangat mendalam tidak hanya bagi warga yang bertikai tetapi seluruh warga yang ada di Kalimantan Tengah. Konflik ini terjadi karena mulai memudarnya rasa saling menghormati dan menghargai diantara penduduk asli dan pendatang. Konflik seperti ini jelas akan mengganggu persatuan dan kesatuan bangsa Indonesia.

Berdasarkan pengamatan peneliti dibeberapa waktu terakhir, peneliti menemukan situasi dimana banyak diantara siswa membentuk kelompok-kelompok kecil. Secara khusus di SMA Kalimantan Tengah selama pengamatan saya pada tanggal 4-11 Agustus 2014, peneliti sering melihat beberapa siswa mengelompok, seke-lompok siswa tersebut terkadang tidak bisa membaur dengan siswa lain dan menganggap kelompoknya yang paling hebat sehingga hal ini dikuatirkan dapat menimbulkan konflik antarkelompok siswa dan siswa lainnya. Konflik tersebut dapat menyebabkan memudarnya rasa persatuan dan kesatuan bangsa di kalangan siswa sebagai generasi muda.

Jika rasa persatuan dan kesatuan bangsa dikalangan siswa semakin memudar maka dikhawatirkan akan terjadi pertikaian, jiwa sosial generasi muda lambat laun semakin memudar, semangat kebangsaan semakin meluntur, bahkan bisa saja banyak generasi muda yang tidak produktif lagi karena hanya mementingkan dirinya sendiri atau hanya terfokus pada kelompok tertentu saja. Sangat disayangkan jika sampai terjadi hal seperti itu. Karena siswa sebagai generasi muda merupakan tonggak estafet pembangunan bangsa Indonesia, sehingga perlu ditumbuhkan lagi rasa persatuan dan kesatuan bangsa di kalangan siswa.

Semangat kebangsaan dan kebanggaan sebagai warga Indonesia juga perlu ditanamkan pada siswa sebagai upaya untuk membina rasa persatuan dan kesatuan bangsa. Menjadi suatu kebanggan bagi bangsa Indonesia dengan beragam budayanya memiliki nilai-nilai positif yang tumbuh dan berkembang dalam masyarakat. Setiap suku bangsa yang ada di Indonesia memiliki budaya masing-masing. Budaya lokal juga mengandung nilai-nilai yang dapat membina rasa persatuan dan kesatuan bangsa. Dalam prespektif budaya, keinginan untuk bersama membentuk persatuan dan kesatuan bangsa merupakan proses sosial yang didorong oleh kesadaran segenap 
masyarakat untuk bersama membangun suatu tatanan kehidupan baru dengan tetap mengakui dan menerima eksistensi budaya asli daerah yang berbeda-beda ciri dan sifatnya. Budaya kehidupan suatu masyarakat berbedabeda dan masing-masing memiliki nilai tambah, seperti budaya "huma betang" dalam kehidupan masyarakat Suku Dayak di Kalimantan Tengah. Huma betang merupakan rumah tradisional suku Dayak di Kalimantan Tengah. Namun huma betang bukan hanya sekedar bangunan, lebih dari sekedar bangunan untuk tempat tinggal masyarakat Suku Dayak, huma betang merupakan cerminan mengenai kebersamaan dalam kehidupan sehari-hari suku Dayak. Suarno (2011, p. 19) mengemukakan "Budaya huma betang merupakan gambaran kebersamaan dalam keseharian hidup orang Dayak yang dulu tinggal di rumah Betang".

Lunturnya rasa persatuan dan kesatuan bangsa pada generasi muda perlu segera ditangani. Menumbuhkan kembali rasa persatuan dan kesatuan bangsa juga bisa dimulai dari budaya-budaya local, seperti budaya huma betang. Nilai budaya huma betang yang dianut masyarakat Suku Dayak di Kalimantan Tengah dilaksanakan berdasarkan peribahaasa kuno Suku Dayak yaitu hong kueh petak ninjakm hete langit inyukahm, yang berarti dimana bumi dipijak, disitu langit dijunjung. Hal ini menunjukkan bahwa Suku Dayak di Kalimantan Tengah sangat menghargai adat istiadat daerah yang ditempatinya, sesuai dengan sifat masyarakat Suku Dayak yaitu belom bahadat (hidup menurut norma).

Masyarakat Suku Dayak sadar pluralitas hadir dalam kehidupan mereka. Namun perbedaan-perbedaan yang ada bukan sebagai pemisah, tetapi bagaimana mengupayakan hidup rukun dan damai berdampingan dengan warga lainnya. Huma betang sebagai sebuah bangunan yang mencerminkan kehidupan bersama dalam suatu wadah dengan berbagai macam karakteristik penghuninya, menghadirkan sebuah budaya huma betang yang merupakan cerminan hidup bersama dalam keberagaman. Budaya huma betang memiliki nilainilai positif yang perlu dilestarikan dan dikembangkan untuk menjaga keharmonisan hidup berdampingan dalam bingkai kehidupan baik dalam keluarga, sekolah, masyarakat, berbangsa dan bernegara. Berdasarkan pemaparan di atas, peneliti tertarik untuk meneliti nilai-nilai budaya huma betang dalam kaitannya dengan pembinaan rasa persatuan dan kesatuan bangsa pada siswa SMA di Kalimantan Tengah.

\section{Metode}

Penelitian ini menggunakan metode penelitian kualitatif dengan pendekatan etnografi. Penelitian ini dilakukan di huma betang desa Bontoi, Kecamatan Kahayan Hilir, Pulang Pisau, Kalimantan Tengah dan di SMA Negeri 1 Kahayan Hilir, yang beralamat di Jalan Bereng Kaling Nomor 9, RT 1, Kecamatan Kahayan Hilir, Kalimantan Tengah. Waktu penelitian sampai konsultasi dilaksanakan selama tujuh bulan. Tiga bulan pertama merupakan masa penelitian dan empat bulan terakhir merupakan waktu analisis dan penulisan tesis serta memperbaiki kekeliruan dalam pengambilan data.

Subjek penelitian yaitu masyarakat yang tinggal di huma betang desa Bontoi, Kecamatan Kahayan Hilir dan siswa SMA Negeri 1 Kahayan Hilir. Penentuan subjek penelitian sebagai sumber data dilakukan dengan teknik snowball sampling, artinya pada tahap awal peneliti akan memilih satu orang yang kemungkinan mengetahui tentang nilai-nilai budaya huma betang, kemudian peneliti mencari tahu orang lain yang mengetahui nilai-nilai budaya huma betang dari informan yang sedang diwawancara. Begitu seterusnya, sehingga jumlah informan semakin banyak.

Data yang diperoleh dalam penelitian ini adalah data kualitatif. Untuk memperoleh data dan informasi yang akurat dan representatif dibutuhkan teknik pengumpulan data yang dipandang tepat. Dalam penelitian ini peneliti sebagai instrumen utama (key instrumen) yang didukung dengan pedoman observasi, pedoman wawancara, dokumentasi.

Proses analisis data dalam rencana penelitian tesis dilakukan secara terus-menerus (continue) dari awal sampai akhir penelitian. Langkah-langkah melakukan penelitian etnografis ini berdasarkan langkah-langkah yang dikembangkan Spradley (2007)yaitu: (1) menetapkan informan; (2) melakukan wawancara etnografis; (3) membuat catatan etnografis; (4) mengajukan pertanyaan deskriptif; (5) melakukan analisis wawancara etnografi; (6) membuat analisis domain; (7) mengajukan 
pertanyaan struktural; (8) membuat analisis taksnomik; (9) mengajukan pertanyaan kontras; (10) Membuat analisis komponen; (11) menemukan tema-tema budaya; (12) menulis sebuah etnografi.

\section{Hasil dan Pembahasan}

Falsafah huma betang merupakan salah satu budaya yang tumbuh dan berkembang pada masyarakat Dayak di Kalimantan Tengah. Budaya huma betang masyarakat Suku Dayak yaitu kebersamaan di dalam perbedaan (together in diversity), artinya ada semangat kesatuan dan persatuan, etos kerja dan toleransi yang tinggi untuk mengelola secara bersama-sama segala perbedaan yang ada dan mampu berkompetisi secara jujur sehingga perbedaan yang ada menjadi sebuah kekuatan untuk bersatu bukan sebagai jurang pemisah. Secara filosofis budaya huma betang di Kalimantan Tengah menggambarkan kebersamaan dalam keberagaman. Hidup bersama dengan berbagai keberadaan masing-masing individu yang memiliki karakter yang berbeda-beda. Dalam keberagaman diperlukan sikap saling menghormati sesuai dengan filosofi hong kueh petak ninjakm hete langit inyukahm yang artinya di mana bumi dipijak di situ langit dijunjung.

Huma betang Buntoi sudah beberapa kali mengalami perbaikan. Dahulu, perbaikan dilakukan secara gotong royong, namun kini huma betang Buntoi sudah menjadi obyek wisata budaya Provinsi Kalimantan Tengah yang juga melalui kabupaten Pulang Pisau sehingga dalam perbaikan dan perawatannya mendapat bantuan dari pemerintah daerah.

Walaupun mengalami beberapa kali perbaikan, ciri khas bangunan huma betang tetap dijaga, yaitu bangunan tinggi, panjang, atap terbuat dari atap sirap (atap yang terbuat dari kayu Ulin yang dibelah tipis sedemikian rupa), dinding dan lantai terbuat dari kayu ulin. Mengenai bangunan huma betang. Riwut (2003, p. 141) mengemukakan bahwa huma betang berukuran besar dan dibangun tinggi dari tanah, untuk menghindari banjir, menghindari musuh yang datang menyerang dengan tiba-tiba, menghindari binatang buas, juga karena tuntutan adat.

Budaya huma betang merupakan salah satu budaya yang tumbuh dan berkembang pada masyarakat Dayak di Kalimantan Te- ngah. Budaya huma betang mengandung nilai-nilai positif yang dapat mendukung pembinaan rasa persatuan dan kesatuan bangsa di tengah masyarakat Indonesia yang multikultural, secara khusus penduduk di Kalimantan Tengah yang juga multikultural. Nilai dianggap sebagai sesuatu yang baik, yang berguna dan dianggap penting oleh masyarakat. Sesuatu dikatakan memiliki nilai apabila memiliki manfaat. Nilai dalam masyarakat bersumber dari norma yang ada di masyarakat. Norma berisi perintah dan larangan yang harus dipatuhi oleh masyarakat demi terwujudnya nilai-nilai. Nilai dan norma merupakan dua hal yang saling berkaitan dan sangat penting bagi terwujudnya kehidupan bersama yang aman, tentram, rukun dan damai demi menjaga kesatuan dan persatuan bangsa. Budaya huma betang memiliki nilai-nilai positif seperti nilai religius, kebersamaan, kejujuran, toleransi, saling menghormati, kerja keras, musyawarah, gotong royong, mencintai alam, displin.

Masyarakat Suku Dayak pada umumnya adalah pribadi yang percaya kepada Tuhan. Mereka mengakui ada kekuatan lain diluar kekuatan manusia. Tidak ada paksaan bagi masyarakat Suku Dayak dalam memilih dan menjalankan agama dan kepercayaannya. Walaupun berbeda-beda agama, tetapi bukan berarti kebersamaan diantara masyarakat luntur. Mereka tetap menjaga kebersamaan. Mereka saling menghormati, walaupun berbeda kepercayaan. Berdasarkan hasil pengamatan peneliti, siswa siswi SMAN 1 Kahayan Hilir menerapkan nilai religus. Pelajaran dimulai dengan berdoa terlebih dahulu. Begitu pula ketika akan mengakiri pelajaran sebelum pulang sekolah, diakhiri dengan berdoa. Siswa siswi SMAN 1 Kahayan Hilir belajar agama sesuai dengan agama dan kepercayaan yang dianutnya. Untuk yang beragama Islam setiap hari Rabu pada jam istirahat yang kedua, semua siswa-siswi yang beragama Islam diwajibkan untuk melaksanakan Sholat Dzuhur berjamaah. Untuk yang beragama Kristen Protestan dan Khatolik mengadakan kebaktian setiap hari Jumat Pukul 11.00 WIB.

Nilai religius yang dimiliki oleh masyarakat Suku Dayak yang dulunya mendiami huma betang ini selayaknya dimiliki oleh segenap masyarakat, tidak hanya terbatas pada masyarakat di Kalimantan Tengah, tetapi di Indonesia. Sebagai manusia ciptaan Tuhan, 
kita perlu bersyukur atas apa yang sudah Tuhan percayakan terjadi dalam kehidupan kita manusia. Jika semua masyarakat di Indonesia sudah benar-benar bisa menjalankan agama dan kepercayaan masing-masing maka semua dapat hidup rukun, damai, tertib. Nilai religius ini selayaknya dimiliki oleh segenap masyarakat, tidak hanya terbatas pada masyarakat di Kalimantan Tengah, tetapi di Indonesia. Negara Indonesia sudah mengatur bahwa setiap warga negara wajib beragama dan diberi kebebasan untuk menjalankan agama dan kepercayaannya masing-masing, hal ini diatur dalam UUD 1945 pasal 29.

Nilai utama yang menonjol dalam kehidupan di huma betang adalah nilai kebersamaan diantara warga penghuninya, terlepas dari perbedaan-perbedaan yang mereka miliki. Kebersamaan juga bermakna kesetaran, duduk sama rendah dan berdiri sama tinggi. Kebersamaan memang indah. Untuk mempersatukan kebersamaan dalam perbedaan itu tidaklah mudah. Manusia tercipta dengan karakter masing-masing yang berbeda satu sama lainnya. Adanya kebersamaan ditengah individuindividu yang memiliki karakter yang berbeda-beda merupakan hal yang indah dan sulit terjadi, inilah yang terjadi di huma betang. Walaupun mereka yang tinggal di huma betang memiliki karakter yang berbeda, mereka dapat hidup bersama. Nilai kebersamaan ini masih terus berlanjut dalam kehidupan bermasyarakat di desa Buntoi ini. Pengalaman peneliti, terjun langsung ke lapangan, masyarakat di sekitar huma betang di desa Buntoi ini masih sering duduk santai bersama di depan rumah maupun di pinggir sungai ketika sore hari sambil menanti matahari terbenam. Ketika ada yang melaksanakan pesta, waktu itu pesta pernikahan, banyak warga yang berkumpul bersama-sama. Hidup di tempat yang sama belum tentu hidup dengan rasa kebersamaan. Tetapi di huma betang seluruh masyarakat yang tinggal di huma betang hidup dalam kebersamaan. Kebersamaan yang terbentuk karena rasa kekeluargaan. Mereka tidak hanya memikirkan diri sendiri tetapi seluruh anggota keluarga di huma betang serta siap berkorban untuk kepentingan bersama. Hal inilah yang coba dilakukan oleh pihak sekolah SMAN 1 Kahayan Hilir terapkan kepada seluruh siswa-siswinya, dengan maksud agar nilai positif dari kebersamaan itu dapat dimanfaatkan dalam meraih prestasi semaksi- mal mungkin dan juga diharapkan siswa-siswi dapat bersama-sama dapat menghambat pengaruh negatif yang dapat memberikan efek buruk bagi siswa-siswi itu sendiri.

Dalam menjalani kehidupannya, masyarakat Suku Dayak yang tinggal di huma betang menjaga nilai kejujuran. Berdasarkan pengamatan peneliti selama di huma betang Buntoi, memang mereka tidak serta merta menggunakan barang-barang yang bukan miliknya. UH ingin menggunakan sepeda milik $\mathrm{FH}$, terlebih dahulu UH meminta izin kepada $\mathrm{FH}$, ketika sudah mendapat ijin baru UH berani menggunakan sepeda milik FH. Berkaitan dengan nilai kejujuran ini, pengalaman peneliti selama mengamati di SMAN 1 Kahayan Hilir, siswa siswi belajar jujur melalui kegiatan bina lingkungan, di mana setiap kelas memiliki taman masing-masing dan diberi tanggung jawab untuk merawatnya. Mereka belajar jujur dengan tidak mengambil tanaman dari kelas lainnya. Mereka menanam dan merawat yang menjadi milik kelas mereka.

Jujur merupakan salah satu sifat manusia yang mulia, orang yang memiliki sifat jujur biasanya mendapat kepercayaan dari orang lain. Bersikap jujur berarti tidak berbohong atau mengatakan yang sebenarnya, tidak mengambil barang orang lain, berbuat curang atau menipu dengan cara apapun. Cherrington \& Cherrington (1993, p. 32) mengemukakan bahwa "Honesty means to be free from deceit and fraud" (Kejujuran berarti bebas dari penipuan dan kecurangan). Orang yang jujur tidak mengatakan hal-hal yang mereka tahu tidak benar, mereka tidak mengambil milik orang lain. Nilai kejujuran dari huma betang sangat berarti jika bisa terus dikembangkan bagi kita saat ini, bukan hanya terbatas pada siswa di SMAN 1 Kahayan Hilir atau hanya pada masyarakat Suku Dayak, tetapi bagi kita, bagi masyarakat di seluruh Indonesia ini. Jujur merupakan sifat manusia yang mulia. Kita tentu tidak menyukai orang yang tidak jujur atau menyampaikan informasi tidak sesuai dengan kenyataan. Terkadang karena ketidakjujuran dapat memicu konflik, atau kesalahpahaman antarsesama. Hal ini tentu mengganggu keharmonisan kehidupan bersama. Maka dari itu kejujuran perlu ditanamkan sejak dini kepada generasi muda, agar genarasi muda sebagai generasi penerus bangsa menjadi pribadi yang jujur sehingga boleh tercipta kehidupan bersama yang har- 
monis dalam bingkai Negara Kesatuan Republik Indonesia (NKRI).

Huma betang mengandung nilai toleransi. Karena perbedaan-perbedaan orangorang yang tinggal di huma betang diperlukan toleransi yang tinggi agar tidak terjadi pertikaian ataupun konflik yang dapat membuat perpecahan. Perbedaan itu adalah anugerah yang patut disyukuri. Perbedaan ada bukan untuk dihilangkan tetapi bagaimana membuat perbedaan itu bisa dihargai untuk memperkuat bangsa kita. Dengan adanya perbedaan manusia bisa saling mendukung dan saling melengkapi. Toleransi merupakan hal yang penting dalam kehidupan bersama ditengah perbedaan. Dengan toleransi yang tinggi, kita yang hidup bersama dapat hidup berdampingan dengan rukun dan damai. Berdasarkan pengamatan peneliti ketika di SMAN 1 Kahayan Hilir, siswa siswi belajar untuk menjaga toleransi, terlihat ketika bulan Ramadhan. Siswa siswi yang nonmuslim makan dan minum di kantin yang agak ditutup kain untuk menghormati teman-teman mereka yang menjalankan ibadah Puasa. Demikian pula ketika waktunya sholat Dzuhur, yang beragama Islam menjalankan ibadahnya dan yang nonmuslim tidak mengganggu.

Pluralisme menjadikan ciri khas negara Indonesia sebagai negara yang memiliki berbagai suku, bahasa, budaya dan adat istiadat. Tuntutan masyarakat untuk dapat hidup damai sebagai satu kesatuan negara haruslah dapat mengembangkan sikap toleransi. Dengan perbedaan yang ada bukan untuk dikedepankan atau ditonjolkan agar tidak terjadi gesekan yang berbau Sara. Sikap toleransi yang tumbuh dari masing-masing individu memberikan nilai tersendiri apabila dia terjun ke lingkup masyarakat yang lebih luas. Tanpa adanya toleransi maka di masyarakat dapat terjadi pertengkaran, perkelahian bahkan bisa sampai mematikan. Toleransi merupakan sikap yang sangat perlu dikembangkan karena manusia adalah makhluk sosial dan akan menciptakan adanya kerukunan hidup.

Sikap saling menghormati sangat ditekankan dalam kehidupan masyarakat Suku Dayak. Mereka yang tinggal di huma betang hidup berdampingan saling menghormati. Berdasarkan pengamatan peneliti selama berada di SMAN 1 Kahayan Hilir, pihak sekolah selalu mengingatkan warga sekolah untuk hidup saling menghormati. Berhubungan de- ngan saling menghormati, Grant (2014, p. 1) mengemukakan "Mutual respect, the fundamental element of human relations." (Saling menghormati, elemen unsur pokok dari hubungan manusia). Saling menghormati merupakan bagian dari kehidupan manusia dengan segala perbedaan yang ada. Pada siswa-siswi SMAN 1 Kahayan Hilir, sikap saling menghormati ini sangat diperlukan untuk mempererat rasa persatuan dan kesatuan. Antarsesama siswa diharapkan dapat saling menghormati, tidak memandang siswa tersebut senior atau junior. Sebab, banyak kejadian yang berujung pada perpecahan yang disebabkan sikap tidak saling menghormati, terlebih dari sikap senioritas di sekolah. Hal ini tentu saja sangat merugikan, sehingga pihak sekolah perlu mengawasi dengan seksama agar hal-hal yang tidak diinginkan dapat dicegah sedini mungkin, salah satunya dengan lebih mengedepankan sikap saling menghormati antar sesama siswa.

Nilai-nilai yang terkandung dalam budaya huma betang selanjutnya adalah nilai kerja keras. Berdasarkan deskripsi ibu El, bangunan huma betang di Kalimantan Tengah pada umunya dibuat hulunya menghadap timur atau searah dengan matahari terbit dan hilirnya menghadap barat atau arah matahari terbenam. Hal ini dianggap simbol kerja keras bagi masyarakat Suku Dayak untuk bertahan hidup mulai dari matahari terbit hingga matahari terbenam. Hulu yang menghadap timur atau arah matahari terbit memiliki makna bahwa berangkat atau mulai bekerja sedini mungkin, semangat bekerja laksana matahari yang terbit di ufuk timur. Sedangkan hilir yang menghadap barat atau matahari terbenam memiliki makna bahwa masyarakat bekerja hingga matahari terbenam. Masyara-kat Suku Dayak yang bekerja, khususnya yang bekerja di ladang atau berburu tidak akan pulang atau berhenti bekerja sebelum matahari terbenam. Mereka yang berladang bekerja keras memanen hasil bumi. Karet disadap dengan turun ke kebun dini hari, sebelum matahari terbit karena getah karet akan mengucur deras pada dini hari dan pada siang hari getah karet akan mengental. Saat siang hari masyarakat Suku Dayak mengambil rotan, pengambilan rotan dilakukan secara selektif, rotan yang akan dipanen adalah rotan yang sudah siap panen untuk menghindari pengrusakan media panjatnya. Memanen ro- 
tan memerlukan perjuangan dan kerja keras karena harus masuk melawan gigitan nyamuk yang tak terelakkan serta ancaman ular berbisa dan binatang buas lainnya. Kebun rotan sering berasosiasi dengan kebun karet yang menghutan, karena prinsip penanaman rotan yang harus memenuhi prinsip kesenyawaan dengan lingkungannya. Kebun rotan yang menghutan sengaja tidak dibersihkan karena apabila dibersihkan, penyinaran matahari akan merusak anakan rotan dan merusak media panjat. Nilai kerja keras yang ada dalam huma betang perlu terus dilestarikan agar kita tetap bekerja keras, bukan memilih jalan pintas untuk menggapai sesuatu yang kita inginkan. Kerja keras berarti bekerja dengan sungguhsungguh, penuh semangat dan pantang menyerah untuk mencapai hasil yang baik. Nilai inilah yang juga diharapkan dapat dilakukan oleh seluruh siswa-siswi SMAN 1 Kahayan Hilir dalam segala aspek kehidupannya. Pihak sekolah perlu menanamkan pemahaman bahwa segala sesuatu tidak didapatkan secara instant, namun memerlukan proses yang panjang, dan itu tentu saja tidak mudah untuk dilakukan, terlebih dalam menggapai cita-cita.

Pada dasarnya setiap penghuni rumah menginginkan kehidupan bersama yang damai. Hidup bersama dalam satu rumah dengan banyak orang dan perbedaan-perbedaan tidak menutup kemungkinan dapat menimbulkan perselisihan. Perselisihan yang bisa timbul dalam kehidupan agar tidak menjadi permasalahan besar harus segera diselesaikan. Untuk menyelesaikan masalah diperlukan musyawarah agar tidak ada pihak yang merasa dirugikan. Begitu pula di huma betang, masyarakat Suku Dayak akan menyelesaikan perselisihan dengan damai dan kekeluargaan. Musyawarah di huma betang terlihat saat diskusi keluarga, hal ini menunjukkan bahwa dalam mengambil keputusan tidak hanya dilakukan secara sepihak tetapi melalui perundingan terlebih dahulu. Diskusi keluarga yang sering dilaksanakan di huma betang yaitu diskusi melaksanakan acara, seperti melaksanakan upacara pernikahan. Keluarga mempelai meminta pendapat keluarga lain agar pelaksanaan upacara pernikahan dapat berjalan dengan baik. Di lingkungan sekolah, musyawarah juga mulai terlihat saat rapat OSIS hingga menyelesaikan konflik yang terjadi diantara warga sekolah. Berdasarkan hasil wawancara peneliti dengan Rs (Guru Bimbingan Konseling di SMAN 1
Kahayan Hilir) biasanya jika ada warga sekolah yang bertikai diselesaikan secara musyawarah di internal sekolah terlebih dahulu.

Gotong royong merupakan ciri khas kehidupan di huma betang, dimana dalam melakukan pekerjaan, baik di dalam maupun di luar huma betang yang memerlukan tenaga kerja massal, maka gotong royong merupakan tradisi kearifan lokal yang mengembangkan karakter olah rasa/karsa yang perlu dilestarikan. Masyarakat Suku Dayak biasa bekerja andep (saling bantu-membantu). Secara alamiah, manusia melakukan interaksi dengan lingkungannya, baik sesama manusia maupun dengan makhluk hidup lainnya sehingga sejak dini kita harus dilatih untuk saling tolong menolong. Nilai gotong royong ini harus terus dilestarikan sebagai warisan leluhur.

Pengalaman peneliti selama mengamati dan ikut dalam kegiatan masyarakat di sekitar huma betang, ketika ada warga yang akan melangsungkan pernikahan, banyak orang desa Buntoi tersebut yang ikut membantu persiapan, mulai dari mempersiapkan bumbu masakan, bahkan sampai mambuat panggung hiburan rakyat. Pada umumnya, yang turut dalam mempersiapkan bumbu masakan memang ibu-ibu, dan pemuda-pemuda yang mencari bahan masakan untuk sayur seperti singkah (umbut) serta mengangkatangkat bahan seperti beras dan sembako lainnya. Selain itu, pemuda desa beserta bapakbapak turut bergotong royong membuat panggung hiburan. Implementasi gotong royong di lingkungan sekolah terlihat saat kegiatan bina lingkungan. Semua warga sekolah, tidak hanya siswa tetapi juga guru beserta staf SMAN 1 Kahayan Hilir bergotong royong membersihkan lingkungan sekolah. Lingkungan sekolah yang bersih membuat suasana belajar menjadi lebih nyaman.

Masyarakat Suku Dayak memiliki naluri untuk selalu hidup bersama secara berdampingan dengan alam dan warga masyarakat lainnya. Mencintai alam dimaknai sebagai rasa peduli terhadap kelestarian lingkungan hidup. Alam merupakan suatu yang amat penting dalam kehidupan kita di bumi ini. Kerusakan alam dapat membawa dampak yang besar bagi kehidupan makhluk hidup yang ada di bumi ini. Jika seseorang mencintai lingkungannya maka dia tidak akan melakukan perusakan terhadap lingkungan hidup, melainkan malah menjaga dan melestari- 
kannya karena dia merasa sebagai bagian dari alam ini. Dengan mencintai alam maka orang akan menghargai lingkungannya dengan memelihara kelestariannya dan tidak sampai hati untuk merusaknya. Implementasi mencintai alam di lingkungan SMAN 1 Kahayan Hilir terlihat pada kegiatan bina lingkungan. Semua warga sekolah diajarkan untuk mencintai alam. Menjaga dan merawat alam sekitar.

Nilai yang juga terkandung dalam budaya huma betang yaitu nilai disiplin. Orang yang disiplin akan selalu mentaati aturan-aturan yang berlaku sehingga dia akan selalu merasa tenteram dan tenang karena tidak melakukan penyimpangan. Disiplin sangat penting karena orang yang disiplin akan menghargai waktu dan memanfaatkan waktu sebaik-baiknya. Disiplin berarti melakukan segala sesuatu sesuai dengan ketentuannya. Disiplin merupakan sikap taat dan patuh. Taat dan patuh terhadap orang tua, guru, dan peraturan-peraturan yang berlaku. Seorang siswa, selama ia menjadi warga sekolah, tidak akan lepas dari berbagai peraturan dan tata tertib yang diberlakukan di sekolahnya, dan setiap siswa dituntut untuk dapat bersikap dan berperilaku seuai dengan tata tertib yang berlaku di sekolahnya. Kedisiplinan di sekolah merupakan proses belajar untuk hidup teratur. Kedisiplinan menjadi suatu latihan yang teraktulisasi dalam tingkah laku yang bertujuan agar siswa patuh pada peraturan. Dengan kita taat dan patuh, kita ikut serta menjaga keharmonisan kehidupan bersama. Hal ini untuk mendukung rasa persatuan dan kesatuan bangsa.

Lingkungan sekolah memiliki peran dalam membina rasa persatuan dan kesatuan bangsa pada siswa. Lingkungan sekolah merupakan contoh dari adanya masyarakat multikultural karena warga sekolah baik itu siswasiswi maupun pengurus sekolah baik kepala sekolah, guru dan pegawai-pegawainya terdiri dari berbagai etnik dan agama. Seperti yang dinyatakan oleh YR (wakil kepala SMA Negeri 1 Kahayan Hilir): "Di sekolah ini terdiri dari berbagai suku dan agama." Memang seharusnya sekolah tidak membeda-bedakan siswa yang mau masuk ke sekolah itu dari segi suku karena bagaimanapun semua warga negara memiliki hak yang sama untuk memperoleh pendidikan yang layak.

Pemanfaatan nilai-nilai huma betang di SMA Negeri 1 Kahayan Hilir dalam mem- bina rasa persatuan dan kesatuan bangsa dilakukan melalui berbagai kegiatan sekolah, baik itu kegiatan intrakurikuler dan ekstrakurikuler. Pembinaan rasa persatuan dan kesatuan bangsa dengan memanfaatkan budaya huma betang dilakukan dalam kegiatan bina lingkungan, OSIS, kegiatan ekstrakurikuler, seperti kerohanian, pramuka, PIK-R (Pusat Informasi dan Konseling Remaja), kesenian, ekstrakurikuler olahraga, dan APEL (Aksi Pelajar Peduli Lingkungan).

Memanfaatkan nilai-nilai budaya huma betang pihak sekolah mengadakan kegiatan aksi bina lingkungn yaitu setiap hari Sabtu Pukul 07.00-07.40 WIB. Kegiatan bina lingkungan ini juga mendukung program sekolah berbasis lingkungan yang mengedepankan kearifan local. Semua warga sekolah, baik siswa, guru serta staf SMAN 1 Kahayan Hilir bersama-sama bergotong royong membersihkan lingkungan sekolah. Dengan lingkungan sekolah yang bersih, suasana belajarpun menjadi nyaman. Kegiatan bina lingkungan ini tidak lepas dari mencontoh budaya hidup Suku Dayak yang mendiami huma betang yang terus memelihara lingkungannya pada setiap waktu. Masyarakat Suku Dayak sadar pentingnya arti menjaga alam sekitar untuk keberlangsungan hidup mereka. Mereka secara rutin membersihkan lingkungan sekitar rumah dengan kegiatan membawau (membersihkan rumput dengan parang) di sekitar tempat tinggal mereka, dan pada waktu tertentu masyarakat juga membersihkan ladang mereka, agar tanaman utama yang mereka tanam dapat bertumbuh dengan baik dan memberikan hasil yang maksimal. Hal itu dilaksanakan secara handep (gotong royong) agar pekerjaan tersebut terasa lebih ringan dan dapat diselesaikan tepat waktu.

Melalui kegiatan bina lingkungan ini warga sekolah diajarkan untuk mencintai lingkungan hidup. Mencintai lingkungan hidup sebagai bentuk kepedulian warga sekolah terhadap alam. Sikap mencintai lingkungan ini dilakukan dengan cara menyadari untuk tidak membuang sampah sembarangan tetapi pada tempat yang sudah disediakan, menjaga kebersihan secara rutin, serta menanam berbagai macam pohon pelindung dan tanaman hias yang semuanya diawali dari lingkungan sekolah. Melalui bina lingkungan diajarkan untuk bermusyawarah, setiap kelas diberikan kesempatan untuk bermusyawarah membuat 
taman yang seperti apa yang akan dibangun di depan kelas mereka, tanaman apa yang akan ditanam. Pihak sekolah juga mengajarkan kejujuran melalui bina lingkungan ini dengan tidak saling mengambil atau merusak bunga atau tanaman yang bukan milik kelas masingmasing.

Melalui bina lingkungan ini juga mengajarkan kebersamaan dan gotong royong, dimana dalam membuat taman kelas, semua warga kelas bersama-sama bergotong royong membuat dan merawatnya. Membuat dan merawat taman beserta tanamannya membutuhkan kerja keras agar menjadi taman yang baik, yang indah dipandang mata, dan menyegarkan. Hal ini menunjukkan kecintaan warga SMA Negeri 1 Kahayan Hilir terhadap alam. Dokumentasi kegiatan bina lingkungan dapat dilihat pada Gambar 1.

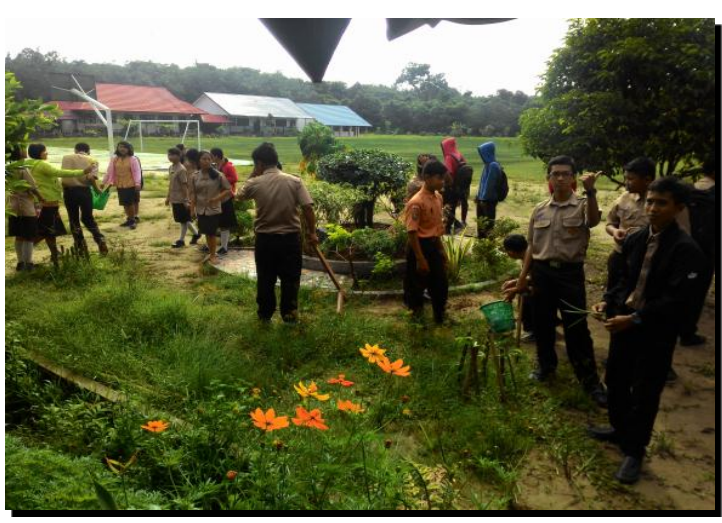

Gambar 1. Kegiatan Bina Lingkungan

Siswa-siswi di SMA Negeri $1 \mathrm{Ka}-$ hayan Hilir juga diharuskan memiliki ketaqwaan yang kuat kepada Tuhannya, sehingga diadakan kegiatan ekstrakulikuler dibidang kerohanian, agar siswa-siswi dapat mempertebal iman dan taqwa terhadap Tuhan masingmasing menurut agama dan kepercayaannya. Bagi siswa-siswi yang beragama Islam, dilaksanakan kegiatan ekstrakulikuler Group Habsyi yang dilaksanakan setiap hari Senin Pukul 14.30-16.30 WIB. Kemudian, pada setiap hari Rabu pada jam istirahat yang kedua, semua siswa-siswi yang beragama Islam diwajibkan untuk smelaksanakan Sholat Dzuhur. Untuk yang beragama Kristen Protestan dan Khatolik mengadakan kebaktian setiap hari Jumat Pukul 11.00 WIB. Sedangkan ekstrakurikuler untuk siswa-siswi yang beragama Kristen adalah Vocal Group dan Paduan Suara Gerejawi. Untuk ekstrakurikuler Vocal Group diadakan hari selasa sampai jumat pukul 15.00-16.30 WIB. Untuk ekstrakurikuler Paduan Suara Gerejawi diadakan hari rabu sampai jumat pukul 15.00-16.30 WIB.

Banyak hal positif yang diperoleh siswa-siswi dengan melaksanakan kegiatan dalam bidang kerohanian ini, antara lain mempererat tali persaudaraan, menangkal berkembangnya kegiatan negatif yang semakin hari semakin merajalela di kalangan mudamudi Indonesia, disamping juga untuk menambah nilai-nilai spiritual quotient (SQ), yaitu kecerdasan spiritual bagi siswa-siswi tersebut. Hal ini menunjukkan bahwa nilai positif yang diperoleh dari budaya huma betang adalah nilai kebersamaan dan toleransi yang dilakukan dalam menjalani kehidupan sehari-hari dapat diajarkan sejak dini dalam kehidupan warga sekolah, khususnya siswa siswi SMA Negeri 1 Kahayan Hilir, salah satunya melalui kegiatan kerohanian, sehingga perpecahan yang mungkin timbul dapat diminimalisir, bahkan dapat dihilangkan

Pemanfaatan nilai-nilai budaya huma betang juga dilakukan di OSIS (organisasi siswa intra sekolah). Karena pada dasarnya masyarakat Suku Dayak sudah terbiasa hidup secara terstruktur. Meskipun tidak masuk dalam organisasi tertentu, masyarakat Suku Dayak tetap berpegang teguh pada kesepakatan bersama yang diatur kedalam suatu peraturan yaitu hukum adat. Dalam penyusunan hukum adat tersebut lebih diutamakan melalui musyawarah, yang dipimpin oleh orang yang dituakan dalam huma betang. Sehingga dapat dihasilkan tatanan kehidupan yang sistematis dan selaras. Berdasarkan hasil wawancara dengan ketua dan anggota OSIS SMAN 1 Kahayan Hilir, nilai-nilai budaya huma betang dimanfaatkan sebagai media guna membina rasa persatuan dan kesatuan bangsa pada siswa siswi di SMA Negeri 1 Kahayan Hilir. Melalui OSIS ini mereka terbiasa belajar bermusyawarah, saling menghargai, saling menghormati, bekerja sama, jujur, disiplin, mencintai alam. Dari OSIS juga merasakan arti sebuah kebersamaan.

Melalui kegiatan ekstrakurikuler kesenian (paduan suara dan seni tari) siswa dapat juga belajar tentang kebersamaan, kerja keras, disiplin, dan juga belajar tentang makna yang tersirat dari setiap gerakan tarian itu sendiri. Setiap kali latihan diperlukan kedisiplinan agar latihan dapat dilaksanakan tepat 
waktu. Pun diperlukan kebersamaan, baik itu oleh penari maupun pemain musik dalam menghasilkan ragam gerak yang dinamis namun tetap seirama, serta diperlukan kerja keras agar kelompok tari dari sanggar tari "Antang Tabela" (kelompok sanggar siswa SMAN 1 Kahayan Hilir) dapat terus mengembangkan kreativitas dan bakat, sehingga diharapkan dapat memperoleh prestasi pada event-event lomba tari yang diikuti. Hasil pengamatan dan dokumentasi peneliti pada saat latihan sanggar tari "Antang Tabela" dapat dilihat pada Gambar 2.

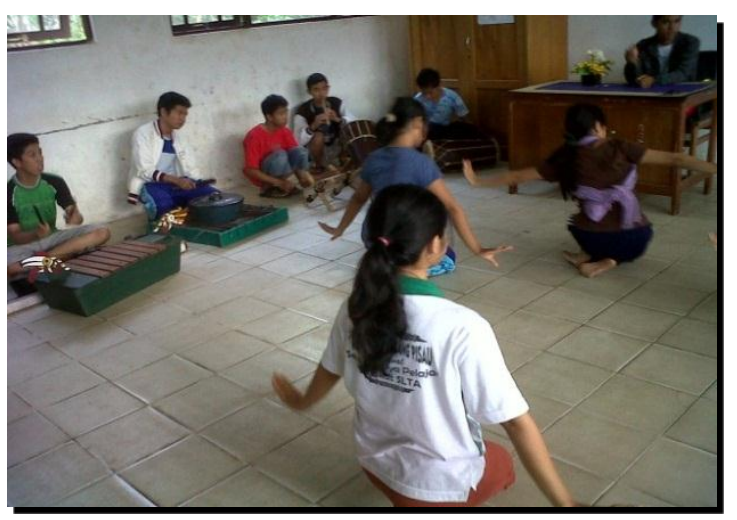

Gambar 2. Kegiatan Latihan Sanggar Tari "Antang Tabela"

Nilai-nilai positif yang terdapat pada falsafah huma betang mendorong sekolah untuk mengadakan kegiatan ekstrakulikuler yang secara nyata menunjukkan kesamaan nilai-nilai luhur dalam membentuk karakter siswa yang sehat. Seperti yang diketahui bersama, kegiatan pramuka merupakan wadah bagi tunas-tunas bangsa dalam membentuk watak, akhlak, dan budi pekerti luhur. Kesamaan yang dimaksud disini ialah nilai-nilai yang terkandung dalam pengamalan Tri Satya dan Dasa Dharma Pramuka sejalan dengan falsafah hidup huma betang. Hal inilah yang kemudian membuat pihak sekolah merasa sangat perlu untuk memasukkan kegiatan ekstrakulikuler ini ke dalam kegiatan siswasiswi SMA Negeri 1 Kahayan Hilir. Kegiatan ekstrakurikuler Pramuka dapat dilihat pada Gambar 3.

Kegiatan ekstrakurikuler lainnya yang memanfaatatkan nilai-nilai budaya huma betang yaitu kegiatan APEL (Aksi Pelajar Peduli Lingkungan). Kegiatan APEL ini dilaksanakan setiap hari Rabu pukul 15.0016.00 WIB. Dalam kegiatan ini, tidak hentihentinya pihak sekolah melalui guru-guru pendamping selalu memberikan pemahamanpemahaman pentingnya nilai-nilai positif dalam tatanan kehidupan bermasyarakat, terutama masyarakat sekolah, khususnya kepedulian terhadap lingkungan.



Gambar 3. Kegiatan Pramuka

Masyarakat Suku Dayak pada umumnya, tidak terkecuali pada masyarakat yang mendiami huma betang memahami pentingnya menjaga alam sekitar. Hal ini tidak terlepas pada kenyataan bahwa manusia tidak bisa lepas dari alam. Masyarakat Suku Dayak sudah turun temurun memanfaatkan kekayaan alam sekitar dalam memenuhi kebutuhannya sehari-hari. Maka dari itu, sekolah perlu membina siswa-siswi untuk mencintai alam sedini mungkin agar kedepannya siswa-siswi sudah terbiasa untuk lebih peduli dengan lingkungan. Kegiatan ini memiliki perbedaan dari kegiatan bina lingkungan, sebab kegiatan ini secara khusus dilakukan oleh pengurus OSIS, serta kegiatan ini tidak hanya dilaksanakan pada lingkungan sekolah, tetapi juga dilaksanakan pada lingkungan luar sekolah. Kegiatan ini bertujuan untuk menimbulkan kesadaran pentingnya mencintai lingkungan kepada masyarakat secara luas. Karena pada dasarnya menjaga lingkungan adalah kewajiban semua pihak, sehingga pihak sekolah yang dimotori oleh pengurus OSIS berinisiatif menjadi leading sector dalam hal menjaga lingkungan. Tentu hal ini merupakan dampak pembinaan yang memadai dari pihak sekolah untuk memberikan pemahaman yang bagus bagi siswa-siswi untuk ikut berperan secara nyata dalam menjaga lingkungan sekitar. Itu semua tidak terlepas dari pentingnya nilainilai positif dari huma betang yang dirasa perlu oleh pihak sekolah sebagai suatu acuan dalam proses pembinaan persatuan dan kesatuan siswa-siswi SMA Negeri 1 Kahayan Hilir. 
Kegiatan ekstrakurikuler olahraga untuk masing-masing siswa dibina agar dapat meningkatkan nilai-nilai positif yang ada pada kegiatan olahraga itu sendiri, baik itu kerja keras, pantang menyerah, kejujuran, dan kerja sama yang baik, guna mendapatkan hasil yang maksimal. Dalam budaya huma betang, masyarakat Suku Dayak dan masyarakat dari luar yang faham akan nilai-nilai hidup Suku Dayak sudah terbiasa dengan nilai-nilai positif yang dimaksud, sehingga pemahaman-pemahaman akan nilai-nilai tersebut dapat dengan mudah diterima oleh masing-masing siswa. Kebanyakan siswa sudah mengerti akan pentingnya kerja keras, pantang menyerah, jujur dan bekerja sama dengan baik, sehingga prestasi yang diharapkan telah banyak dimenangkan oleh siswa-siswi SMA Negeri 1 Kahayan Hilir.

Kegiatan ekstrakurikuler dibidang olahraga yaitu sepak bola, bola basket, volly, tenis meja, silat, atletik. Di bidang keolahragaan banyak siswa yang meraih prestasi (dokumen terlampir) Hal ini menunjukkan bahwa nilai-nilai positif yang ditanamkan pada siswa-siswi SMA Negeri 1 Kahayan Hilir dapat menjadi prestasi yang membanggakan, khususnya dalam bidang olahraga. Walaupun tidak mencapai prestasi, melalui kegiatan olahraga ini dapat membina kebersamaan, usaha, kerja keras, pantang menyerah dan tubuh yang sehat. Di bawah ini hasil dokumentasi kegiatan ekstrakurikuler tenis meja di SMA Negeri 1 Kahayan Hilir.

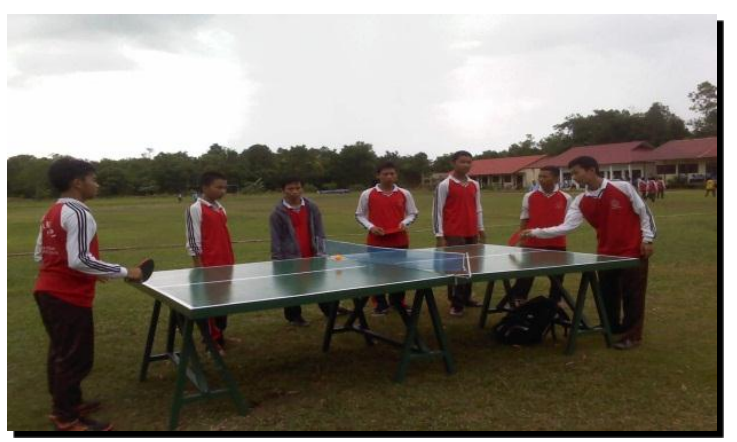

Gambar 4. Kegiatan Ekstrakurikuler Tenis Meja

Pemanfaatan nilai-nilai budaya huma betang juga dilaksanakan melalui kegiatan Pusat Informasi dan Konseling Remaja (PIKR). PIK-R adalah salah satu wadah bagi siswa-siswi SMA Negeri 1 Kahayan Hilir untuk memberikan informasi tentang penyiapan kehidupan keluarga bagi remaja (PKKBR), pendewasaan usia perkawinan, keterampilan hidup, pelayanan konseling dan rujukan PKKBR. Kegiatan ekstrakulikuler ini memberikan kesempatan bagi siswa-siswi untuk meningkatkan keterampilan hidupnya (life skills) dan sejak dini dapat menghindari bahaya-bahaya yang sedang mengintai mereka, yaitu berupa obat-obatan terlarang, pergaulan bebas, dan penyakit seksual menular. PIK-R juga memiliki slogan salam gender, yang berarti bahwa kegiatan ini menjunjung tinggi asas emansipasi manusia, yaitu laki-laki dan perempuan memiliki derajat yang sama dalam kehidupan sehari-hari. Kegiatan PIK-R di bawah bimbingan ibu Roesnawaty terus berkembang. Bimbingan melalui PIK-R dapat mengajaran kebersamaan kepada siswa, kejujuran untuk mengungkapkan isi hatinya (curhat), kerja keras, musyawarah untuk menyelesaikan masalah.

Pemanfaatan nilai-nilai budaya huma betang selanjutnya melalui kegiatan Perayaan HUT SMA Negeri 1 Kahayan Hilir dan Perpisahan Kelas XII. Kegiatan ini merupakan kegiatan rutin yang dilakukan SMA Negeri 1 Kahayan Hilir setiap tahunnya. Melalui kegiatan perayaan Hari Ulang Tahun SMA Negeri 1 Kahayan Hilir ini, diharapkan dapat lebih mempererat hubungan warga sekolah. Selain mempererat hubungan antar warga sekolah, kegiatan ini juga menjadi salah satu ajang silahturahmi dengan tamu undangan. Dan, kegiatan perayaan HUT ini juga memiliki arti yang sangat berkesan bagi warga sekolah karena memberikan kesempatan untuk bersyukur atas Rahmat Tuhan yang Maha Kuasa yang telah memberikan wadah untuk dapat memperoleh ilmu pengetahuan yang layak serta pengalaman, terutama bagi siswasiswi SMA Negeri 1 Kahayan Hilir.

Memanfaatkan nilai-nilai budaya huma betang dalam membina rasa persatuan dan kesatuan bangsa pada siswa di SMA Negeri 1 Kahayan Hilir tidak selamanya berjalan mulus karena masih masih terdapat siswa yang saling mengolok-olok, hal ini karena ada perbedaan karakter diantara siswa. Berdasarkan hasil wawancara saya dengan $\mathrm{Ag}, \mathrm{Pt}, \mathrm{Md}, \mathrm{Rj}$ dan Jy, sebagai siswa SMA Negeri 1 Kahayan Hilir, mereka mengemukakan bahwa memang masih ada siswa yang saling mengejek teman yang berbeda suku. Di SMA Negeri 1 Kahayan Hilir terdapat ber- 
bagai siswa dengan berbagai latar belakang. Hal ini terkadang bisa menjadi bahan "bully". Karena perbedaan suku dapat menyebabkan saling mengejek contohnya mengejek logat suku tertentu.

Membina rasa persatuan dan kesatuan bangsa tidak selalu berjalan mulus karena masih ada siswa-siswi yang menganggap dirinya paling baik. Untuk mengatasi kendalakendala dalam membina rasa persatuan dan kesatuan bangsa, pihak sekolah selalu mengingatkan agar seluruh warga sekolah hidup rukun, saling menghormati, saling menghargai dan toleransi. Pada setiap kesempatan pihak sekolah mengingatkan dan mengarahkan serta menjadi teladan untuk tumbuh bersama dalam harmonisasi sesuai dengan motto sekolah growing together in harmony." Jika sampai terjadi perkelahian akan ditangani pihak sekolah bersama guru bimbingan konseling. Pun demikian dengan pembinaan yang dilaksanakan pihak sekolah melalui kegiatan-kegiatan ekstrakulikuler tersebut juga diharapkan mampu menumbuhkembangkan nilainilai positif untuk menjaga kesatuan dan persatuan bangsa, khususnya antar sesama siswa di SMA di Kalimantan Tengah.

\section{Simpulan}

Berdasarkan hasil penelitian dan pembahasan dapat disimpulkan sebagai berikut; (1) secara filosofi, budaya huma betang di Kalimantan Tengah menggambarkan kebersamaan dalam keberagaman; (2) bangunan huma betang (Rumah Betang) di Kalimantan Tengah sudah mulai tidak menjadi tempat tinggal utama, banyak masyarakat Suku Dayak yang lebih memilih rumah tunggal, tetapi dari segi budaya, nilai-nilai yang terkandung dalam Huma Betang masih ada sampai saat ini; (3) budaya huma betang memiliki nilainilai positif seperti nilai religius, kebersamaan, kejujuran, toleransi, saling menghormati, kerja keras, musyawarah, gotong royong, mencintai alam, displin; (4) pemanfaatan nilai-nilai huma betang di SMA di Kalimantan Tengah dalam membina rasa persatuan dan kesatuan bangsa dilakukan melalui berbagai kegiatan sekolah, baik itu kegiatan intrakurikuler dan ekstrakurikuler. Pembinaan rasa persatuan dan kesatuan bangsa dengan memanfaatkan budaya huma betang dilakukan dalam kegiatan ekstrakurikuler, seperti ekstra- kurikuler pramuka, ekstrakurikuler PIK-R, ekstrakurikuler kerohanian, ekstrakurikuler kesenian, ekstrakurikuler olahraga, dan ekstrakurikuler APEL (Aksi Pelajar Peduli Lingkungan); (5) pemanfaatan budaya Huma Betang dalam pembinaan rasa persatuan dan kesatuan bangsa pada siswa SMA di Kalimantan Tengah juga mengalami kendala, seperti masih adanya siswa yang saling mengejek; (6) untuk mengatasi kendala-kendala dalam Pemanfaatan budaya Huma Betang dalam pembinaan rasa persatuan dan kesatuan bangsa pada siswa SMA di Kalimantan Tengah Negeri 1 Kahayan Hilir, pihak sekolah pihak sekolah selalu mengingatkan agar seluruh warga sekolah tumbuh bersama dalam harmonisasi, hidup rukun, saling menghormati, saling menghargai dan toleransi.

Berdasarkan simpulan di atas, dapat dikemukakan implikasi secara teoretis dan praktis dari hasil penelitian ini. Adapun implikasi dari hasil penelitian ini adalah sebagai berikut: (1) implikasi Teoritis. Hasil penelitian ini menunjukkan bahwa budaya Huma Betang memiliki nilai-nilai positif dan dapat dimanfaatkan untuk membina rasa persatuan kesatuan bangsa. (2) implikasi Praktis. Secara praktis, hasil penelitian ini dapat dijadikan sebagai bahan pertimbangan bagi kepala sekolah, guru dan staf di Kalimantan Tengah untuk mengajarkan dan menjadi teladan da-lam upaya memelihara dan mengaplikasikan budaya Huma Betang agar terbinanya rasa persatuan dan kesatuan bangsa sehingga dapat turut serta menjaga tegaknya Negara Kesatuan republik Indonesia.

Berdasarkan hasil penelitian yang telah diperoleh, maka terdapat beberapa saran yang peneliti perlu sampaikan yaitu: (1) Kepala Sekolah sebagai pengambil kebijakan, hendaknya menyarankan kepada para guru untuk mengintegrasikan nilai-nilai budaya huma betang dalam proses pembelajaran. (2) Perlu adanya kegiatan yang membangun ketertarikan generasi muda terhadap budaya lokal di Kalimantan Tengah, seperti mengadakan lomba penulisan sejarah tentang Kalimantan Tengah maupun kegiatan-kegiatan festival yang membangkitkan kreatifitas dengan kecintaan generasi muda terhadap budaya lokal. (3) Para peneliti lain disarankan untuk mengadakan penelitian lanjutan agar penelitian ini semakin sempurna dengan lokasi penelitian di Huma Betang yang masih men- 
jadi tempat tinggal agar memiliki pengalaman yang lebih banyak.

\section{Daftar Pustaka}

Cherrington, D. J., \& Cherrington, J. O. (1993). Understanding honesty. Internal Auditor, 50(6).

Grant, L. (2014). Principle no.6 mutual respect. Jurnal ProQuest, 49(43).

Riwut, T. (2003). Maneser panatau tatu hiang: menyelami kekayaan leluhur.
Palangka Raya: Pusakalima: Jaringan Informasi Pusat Kalimantan (Jari Pusaka).

Spradley, J. P. (2007). Metode Etnografi, terj. Misbah Zulfa Elizabeth, Yogyakarta: Tiara Wacana.

Suarno, D. T. (2011). Budaya rumah betang sebagai simbol kebersamaan kehidupan suku Dayak. Yogyakarta: Panitia PSBDK IX Tahun 2011 dan LSD Yogyakarta. 